Pamiętnik Literacki 2016, 2, s. 5-17
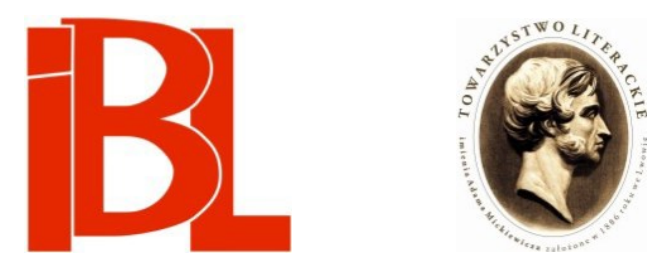

\title{
Uwagi do wciąż nie napisanej historii męskości w Polsce
}

Tomasz Tomasik 


\section{1. $\begin{array}{lllllllllllllllllll} & \mathrm{R} & \mathrm{O} & \mathrm{Z} & \mathrm{P} & \mathrm{R} & \mathrm{A} & \mathrm{W} & \mathrm{Y} & \mathrm{I} & \mathrm{A} & \mathrm{R} & \mathrm{T} & \mathrm{Y} & \mathrm{K} & \mathrm{U} & £ & \mathrm{Y}\end{array}$}

Pamiętnik Literacki CVII, 2016, z. 2, PL ISSN 0031-0514

TOMASZ TOMASIK Akademia Pomorska, Słupsk

\section{UWAGI DO WCIĄż NIE NAPISANEJ HISTORII MĘSKOŚCI W POLSCE}

„Amerykańscy mężczyźni nie mają historii” - z takiego założenia wychodzi socjolog Michael Kimmel w książce Manhood in America. A Cultural History ${ }^{1}$. To spostrzeżenie ujawnia pewien paradoks, bo oczywiście w bibliotekach zalegają całe stosy książek napisanych przez mężczyzn i o mężczyznach - o ich dokonaniach politycznych, militarnych, ekonomicznych czy artystycznych, o wydarzeniach historycznych, w których brali udział, o instytucjach, które zakładali i prowadzili. Rozległej wiedzy o ich życiu prywatnym i społecznym dostarcza literatura, szczególnie teksty autobiograficzne, biograficzne oraz epistolarne. Ich wizerunki utrwaliła sztuka, ikonografia i kinematografia. Problem polega na tym, że nie zbadano historii amerykańskich mężczyzn właśnie jako mężczyzn, w ich płciowej specyfice, czyli nie został opisany skomplikowany proces historycznego kształtowania się ich męskich tożsamości. Książka Kimmela, rzecz jasna, wypełnia tę lukę, ale też niejako przy okazji zarysowuje metodologię i metodykę takich badań, które powinny być prowadzone w ujęciu jak najbardziej interdyscyplinarnym. W realizacji tego rodzaju przedsięwzięcia nieodzowna staje się wiedza $z$ zakresu historii i socjologii, lecz także ekonomii, psychologii, historii sztuki, literatury, mediów, a nawet mody, wojskowości czy sportu. Obszarem badawczym jest tu w istocie szeroko rozumiana kultura w jej wymiarze symbolicznym i zarazem antropologicznym, czyli to, czym w tradycji anglosaskiej zajmuje się dziedzina naukowa określana mianem „historii kulturowej [cultural history]"2.

Warto zajrzeć zarówno do książki Kimmela, jak i do prac innych autorów podejmujących się takiego zadania - głównie dlatego, że nauki humanistyczne i społeczne w Polsce stoja przed podobnym wyzwaniem: polscy mężczyźni nie maja historii. Musi ona zostać dopiero rozpoznana, opisana i zapewne nie raz zweryfikowana. Literaturoznawstwu przypada bardzo istotny udział w tym interdyscyplinarnym przedsięwzięciu badawczym. Piśmiennictwo, obejmujące nie tylko dzieła literackie, ale także wypowiedzi naukowe, popularnonaukowe, publicystyczne, propagandowo-polityczne, praktyczno-użytkowe, dokumenty życia społecznego, stanowi ogromne tekstowe archiwum historii mężczyzn. Można, oczywiście, zrealizować ten projekt poprzez badania cząstkowe, skoncentrowane na określonych przedziałach czasowych, analizach ograniczonych do epok historycznych, poszcze-

M. Ki m m el, Manhood in America. A Cultural History. New York 1996, s. 1.

Zob. P. Bu r ke, Historia kulturowa. Wprowadzenie. Przeł. J. H u ni a. Kraków 2012. 
gólnych autorów czy dzieł, ale celem finalnym powinna być próba wytyczenia trajektorii męskich tożsamości w Polsce (raczej wielu jej linii rozwojowych niż jednej).

Jak zatem pisać historię męskości? Przede wszystkim wypada respektować podstawowe ustalenia socjologiczne i antropologiczne obowiązujące w men's studies - studiach dotyczących mężczyzn, czy też w masculinity studies, studiach koncentrujących się na męskości (a ściśle: na męskościach) ${ }^{3}$. Wszystkie te założenia są wynikiem zdecydowanego odwrotu od esencjalistycznego postrzegania płci. Wskażmy najważniejsze $z$ nich.

\section{Założenia}

Po pierwsze, męskość jest konstruktem socjokulturowym. W większym stopniu zależy od kultury niż od biologii, jest wytwarzana i przetwarzana przez społeczeństwo. Nie istnieje żadna jej stała, ponadczasowa, uniwersalistyczna „istota” ani „natura”, mimo iż w ujęciach religijnych, filozoficznych czy nawet socjologicznych i psychologicznych, najczęściej odwołujących się do binarnej koncepcji płci, tak ją właśnie przedstawiano. Od dualistycznej logiki esencjalizmu oraz fallogocentrycznego myślenia nie była wolna ani literatura, ani cała kultura symboliczna. To właśnie zastosowanie perspektywy historycznej ujawnia różne sposoby kształtowania się w różnym czasie różnych odmian męskich tożsamości. Należy jeszcze dodać, że męskość jest nie tylko konstruowana przez społeczeństwo, ale także interioryzowana przez jednostki, ustanawia ją zewnętrzna struktura relacji płciowych, a równocześnie indywidualne doświadczenie płciowości, seksualności, cielesności, emocjonalności, intymności. Dlatego też warto posługiwać się w studiach maskulinistycznych wprowadzonym przez Pierre'a Bourdieu terminem „habitus”, który francuski socjolog definiował jako „system trwałych i przekazywalnych dyspozycji”" ${ }^{4}$ określających sposób działania, myślenia, wyrażania emocji jednostki zdeterminowanej przez strukturę społeczną. W tak zarysowanej perspektywie badawczej dzieła literackie należałoby traktować jako tekstowe przejawy męskiego habitusu.

Po drugie, nie istnieje jedna uniwersalna męskość, tylko różne jej warianty, dające się rozpoznać w przekrojach zarówno diachronicznych, jak i synchronicznych. Można ją postrzegać z punktu widzenia ewolucji historycznej, lecz także stratyfikacji społecznej. Heterogeniczność męskości jest wynikiem konkretnych, mniej bądź bardziej rozciagniętych w czasie, procesów dziejowych, takich jak np. zmiana systemu ekonomicznego $\mathrm{z}$ feudalnego na kapitalistyczny, wojny dynastyczne i domowe, pojawienie się miast, nowoczesnej nauki, przemysłu, techniki i technologii, ale zarazem trajektorie historii mężczyzn ujawniają swą genealogię $\mathrm{w}$ - rozwijanej przez metodologię Fernanda Braudela - perspektywie czasowej długiego trwania (longue durée). Z kolei w przekrojach synchronicznych różne odmiany

3 Zob. M. Filipowicz, Men's studies / masculinity studies. Hasło w: Encyklopedia gender. Pteć w kulturze. Red. M. Rud a ś - G r od zk a [i in.]. Warszawa 2014, s. 305.

4 P. Bourdieu, Szkic teorii praktyki poprzedzony trzema studiami na temat etnologii Kabylów. Przeł. W. Kr o k e r. Kęty 2007, s. 197. Zob. też tego autora: Męska dominacja. Przeł. L. Ko p ci ewi c z. Warszawa 2004, s. 150. 
męskich tożsamości definiują się w odniesieniu do takich kategorii, jak klasa społeczna, wiek, wyznanie religijne, rasa, narodowość czy orientacja seksualna. Hierarchię tych tożsamościowych referencji każda $z$ epok ustanawiała w sobie właściwy sposób ${ }^{5}$. Robert W. Connell (po korekcji płci: Raewyn Connell) w klasycznej już pracy Masculinities zauważa, że to, co potocznie zwykliśmy określać mianem męskości, w istocie jest jej dominującym w danym społeczeństwie wariantem, zajmującym uprzywilejowana pozycję w złożonej i wciąż ewoluującej strukturze relacji płciowych. Pozycję - dodajmy - zarazem na wiele sposobów legitymizowana, jak i kwestionowana ${ }^{6}$. Australijska badaczka klasyfikuje cztery możliwe warianty relacji zachodzących między odmianami męskości: hegemonia, podporządkowanie, współudział, marginalizacja. Wskazuje też na cztery struktury, w ramach których ustanawiają się owe relacje: pierwsza - władza, czyli polityka; druga - produkcja, czyli ekonomia i podział pracy; trzecia - kateksja, czyli seksualność; czwarta (dodana w późniejszej książce ${ }^{7}$ - symbolizacja, czyli kulturowe reprezentacje płci.

Po trzecie, męskość definiuje się nie tylko w relacji do kobiet, ale także, a niekiedy przede wszystkim, w relacji do innych mężczyzn. W procesie kształtowania się męskiej tożsamości polaryzacja płci ma nie mniejsze znaczenie niż homosocjalizacja. Tego podwójnego uwikłania męskiej tożsamości, która równocześnie usiłuje sprostać podwójnym, kobiecym i męskim, oczekiwaniom, nie dostrzegała do pewnego momentu perspektywa feministyczna. Klasyczna teoria patriarchatu obsadzała mężczyzn dość jednoznacznie w roli oprawców kobiet i demaskowała męskie sojusze, zawiązywane w celu utrzymania politycznej i symbolicznej władzy. Wsparcia teoretycznego udzieliła filozofia poststrukturalistyczna, szczególnie koncepcja Jacques'a Derridy, który zwrócił uwagę na dominacje fallogocentryzmu w systemie europejskiej metafizyki ${ }^{8}$. Dopiero późniejsze badaczki feministyczne, np. Élisabeth Badinter czy Susan Faludi ${ }^{9}$, stwierdziły, że zarówno sam patriarchat, jak i ideologie męskości hegemonicznej mogą oddziaływać opresyjnie także na mężczyzn.

Po czwarte, męskość ustanawiała w kulturze matrycę normatywności. Pisał Bourdieu:

Siła męskiego porządku wynika $z$ tego, że obchodzi się on bez uzasadnień: androcentryzm narzuca się jako neutralny i nie wymagający dyskursywnej legitymizacji. Porządek społeczny jest bowiem olbrzymią machiną symboliczną wprowadzającą w życie i zatwierdzającą męską dominację, na której on sam jest oparty ${ }^{10}$.

Zob. J. H. Arnold, S. Brady, Introduction. W zb.: What Is Masculinity? Historical Dynamics from Antiquity to the Contemporary World. Ed. J. H. Arnold, S. Brady. London - New York 2011, s. 4.

6 R. W. Con nell, Masculinities. Berkeley - Los Angeles 1995, s. 76.

7 R. Co on nell, Socjologia płci. Płeć w ujęciu globalnym. Przeł. O. Si a r a. Warszawa 2013, s. 145. Angielski pierwodruk: Gender in World Perspective. Cambridge 2002.

8 Zob. A. Mar z e c, Fallogocentryzm. Hasło w: Encyklopedia gender, s. 128-130.

9 Myślę tu głównie o takich pracach, jak: É. B a din ter, XY. Tożsamość mężczyzny. Przeł. G. Pr z ewł o c ki. Wstęp M. J a n i o n. Warszawa 1993. - S. Falu di, Stiffed. The Betrayal of the American Man. New York 1999.

B o u r di e u, Męska dominacja, s. 18. 
Wszystko to, co nie jest „męskie”, zostaje potraktowane jako „inne” albo w najbardziej skrajnych przypadkach wręcz uznane za dewiację. Normatywność męskości w sposób szczególny zaznacza się w języku, a zatem również w tekstach literackich, które współtworzą mechanizm męskiej dominacji nad kulturą symboliczną. Mężczyźni nie tylko mówią o sobie, ale jednocześnie uzurpuja sobie prawo do mówienia w imieniu kobiet. Teksty literackie pełnią oczywiście także funkcję subwersywną. Historia mężczyzn, jako dziedzina wiedzy, wyłaniała się ze sporymi oporami i opóźnieniem w porównaniu z historią kobiet. German Ritz tłumaczy to przyczynami dwojakiego rodzaju:

Jedna wiąże się na pewno $\mathrm{z}$ odrzucaniem idei badań uprawianych przez tych, których badania dotyczą, druga - z niechęcią do refleksji nad własną odmiennością, gdy swoją płeć uważa się za to, co ogólne ${ }^{11}$.

Po piąte, męskość była postrzegana w różnych kulturach (także w europejskiej) jako zadanie. „Nieświadomie więc zakłada się, iż kobiecość jest stanem naturalnym, zastanym i nieuniknionym, podczas gdy męskość jest czymś, co trzeba zdobywać w trudzie i ciągle udowadniać" - pisze Badinter ${ }^{12}$. Kimmel uważa, że idea testowania mężczyzn ma charakter strukturalny i dotyczy nie tylko czynów wojennych, ale głównie takich transhistorycznych obszarów życia społecznego, jak praca, polityka i rodzina ${ }^{13}$. W dawnych społeczeństwach tradycyjnych socjalizacja mężczyzn, na co uwagę zwracają antropologowie, odbywała się za pomocą rytuałów inicjacyjnych, często bardzo brutalnych, krwawych i traumatycznych ${ }^{14}$. Młody adept dopiero po przejściu próby męstwa mógł zostać uznany za prawdziwego, pełnoprawnego, dorosłego mężczyznę. Rytualny charakter miały również takie męskie zajęcia, jak polowanie, pojedynek, a przede wszystkim udział w wojnie.

Po szóste wreszcie, last but not least, historia mężczyzn spisywana na podstawie dzieł literackich jest zawsze historiograficzną narracja porządkująca tekstowe reprezentacje męskości. Należy zatem brać pod uwagę dwie sprawy: 1) żadne dzieła symboliczne (literackie, ikonograficzne, filmowe) nie odwzorowują bezpośrednio rzeczywistego życia mężczyzn, tylko je przedstawiają z punktu widzenia jakiejś określonej perspektywy ideologicznej i estetycznej; tekstowe reprezentacje męskości mają charakter partykularny, co często zostaje ujawnione już na poziome genologicznym (np. antyczny epos, średniowieczna historiografia i hagiografia, humanistyczna liryka, dramat mieszczański, powieść gotycka); 2) tworzone przez badaczy - odwołajmy się do pierwszej z tez narratywistycznych sformułowanych przez Franka Ankersmita - „Narracje historyczne są interpretacjami przeszłości”, a zatem nie opisuja obiektywnych sekwencji faktów ${ }^{15}$.

G. Rit z, Granice i perspektywy gender studies. W: Nić w labiryncie pożądania. Gender i płeć $w$ literaturze polskiej od romantyzmu do postmodernizmu. Warszawa 2002, s. 11 (przeł. M. Łu kasiewicz).

Ki m mel, op. cit., s. 2.

Zob. np. D. D. Gilmore, Manhood in the Making. Cultural Concepts of Masculinity. New Haven 1990, zwłaszcza rozdz. 7: Rites of Manhood: Sambia.

15 F. Ankersmit, Sześć tez o narratywistycznej filozofii historii. W: Narracja, reprezentacja, do- 
Kimmel, przystępując do pisania historii męskości w Ameryce, miał zadanie o tyle prostsze, że brał pod uwagę okres od końca XVIII wieku, kiedy to ukonstytuowało się społeczeństwo amerykańskie. Badania przeprowadzane pod znakiem gender studies skupiają się najczęściej właśnie na epoce nowoczesności, szczególnie na wieku XIX, nie tylko ze względu na bezpośrednią bliskość czasową, ale też $\mathrm{z}$ powodu doniosłości zmian, które się dokonały w tym okresie. $\mathrm{W}$ ciągu ostatnich 200 lat nastapiła w kulturze Zachodu zasadnicza ewolucja w postrzeganiu relacji płciowych: od motywowanego różnicami biologicznymi esencjalizmu do inspirowanego różnicami kulturowymi konstruktywizmu. Gender awansowało do rangi kategorii historycznej ${ }^{16}$.

Literaturoznawcze analizy, odsłaniające różne aspekty historii mężczyzn w Polsce, także koncentrują się w głównej mierze na okresie od wieku XIX. Wyjątkiem, ale solidnie udokumentowanym, jest książka Tomasza Nastulczyka i Piotra Oczki Homoseksualność staropolska ${ }^{17}$, która stanowi bardzo ważny przyczynek do badań maskulinistycznych. Wydaje się, że to właśnie epoka staropolska, a ściślej: epoka określana w tradycji anglosaskiej mianem wczesnej nowoczesności (między XV a XVIII wiekiem), była istotnym etapem w dziejach męskości w Polsce. W okresie tym wykształciły się podstawowe męskie habitusy, które, mimo rozmaitych modyfikacji, okazały się nadzwyczaj żywotne i wpisały się - przywołajmy diagnozę Przemysława Czaplińskiego - w trwający od 200 lat konflikt między sarmackością a nowoczesnością, między tradycją a modernizacją ${ }^{18}$.

Należałoby zatem zapytać: jakie zdarzenia i procesy (polityczne, militarne, społeczne, kulturowe, ekonomiczne itd.) odegrały decydująca rolę w wytyczeniu historycznych trajektorii różnych odmian męskości w okresie wczesnonowoczesnym? Który ze wzorów męskiej tożsamości okazał się dominujący? Które znalazły się na marginesie życia społecznego? W jaki sposób teksty literackie biernie rejestrowały, ale też czynnie inicjowały owe zdarzenia i procesy?

Connell, szkicując w zarysie historię męskości, akcentuje przede wszystkim etapy kształtowania się w kulturze europejskiej, a potem północnoamerykańskiej jej formy hegemonicznej, opartej na dominacji, agresji, opresji wobec kobiet oraz na heteronormatywności ${ }^{19}$. Początek przemian, które doprowadziły do ustanowienia nowoczesnego porządku płci, wyznacza on na wstępną fazę renesansu. W ciągu dwóch stuleci między 1450 a 1650 rokiem Europa Zachodnia stała się globalnym imperium, czerpiącym bogactwa z zamorskich kolonii i opierającym się na nowej, kapitalistycznej ekonomii. Decydujące okazały się cztery czynniki rozwojowe, które warto przytoczyć, opatrując je dodatkowym komentarzem, i wstępnie, ekspery-

świadczenie. Studia z teorii historiografii. Red., wstęp E. D o m a ń s k a. Kraków 2004, s. 55 (przeł. E. Domańska).

16 Zob. G. Ritz, Wprowadzenie. W zb.: Nowa świadomość płci $w$ modernizmie. Studia spod znaku gender $w$ kulturze polskiej $i$ rosyjskiej $u$ schytku stulecia. Red. G. Ritz, Ch. Binswanger, C. S ch eid e. Kraków 2000, s. 10.

17 T. Na s tu lc zy k, P. O c z k o, Homoseksualność staropolska. Przyczynek do badań. Kraków 2012.

18 P. C za plińs ki, Resztki nowoczesności. Dwa studia o literaturze i życiu. Kraków 2011, tu „pierwsze studium": Resztki tradycji. Sarmatyzm, uwłaszczenie ciał i późna nowoczesność.

19 C onne11, Masculinities, s. 185-191. W dalszej części artykułu odwołuję się do tego fragmentu książki. 
mentalnie, „przymierzyć” do literatury polskiej okresu wczesnonowoczesnego, wchodząc tym samym na obszar terra incognita.

\section{Historia męskości a załamanie się formacji kulturowej chrześcijaństwa monastycznego}

Renesansowy humanizm zainicjował nowy sposób myślenia o człowieku jako osobie autonomicznej, autorefleksyjnej, odkrywającej wszelkie możliwe wymiary swego człowieczeństwa (humanitas), również te wyparte, cenzurowane bądź napiętnowane przez średniowieczny katolicyzm - jak płeć czy seksualność. W życiu społecznym i prywatnym, wyzwalającym się stopniowo spod wpływu monastycznego kultu celibatu i dziewictwa, $\mathrm{z}$ jednej strony dokonywała się nobilitacja bardziej smiałych relacji heteroseksualnych, niekoniecznie małżeńskich, o czym świadczą chociażby renesansowa i barokowa poezja erotyczna lub też takie dzieła, jak Dekameron Boccaccia, a $z$ drugiej - bardziej przychylnie traktowano miłość homoerotyczną, czego wyrazem może być twórczość Marlowe’a (poemat Hero i Leander, dramat Edward In) czy Szekspira (Sonety).

Kultura staropolska, obstając przy identyfikacji z tradycyjną religijnością katolicką, odnosiła się z dezaprobatą do bardziej liberalnych zachowań obyczajowych, naruszających normę heteroseksualności i monogamiczności. Dość dobrze ilustruje to porównanie dwóch dzieł: włoskiego Il Cortegiano pióra Baldassarre Castiglionego i jego „ocenzurowanego” przekładu Dworzanin polski dokonanego przez Łukasza Górnickiego. Oba utwory zostały napisane $z$ wybitnie męskiej perspektywy - jednakże autor włoskiego oryginału zaprezentował kobiety jako równoprawne pod względem inteligencji i elokwencji partnerki w rozmowach $z$ mężczyznami, wypowiadające prywatne, niezależne sądy na tematy tak śmiałe, jak chociażby rozkosze miłości, podczas gdy polski tłumacz w istotny sposób ograniczył rolę kobiet w życiu dworskim, nie przyznał im prawa do własnego głosu ${ }^{20}$, usunął co bardziej kontrowersyjne fragmenty odnoszące się do zachowań hetero- i homoseksualnych ${ }^{21}$. W kulturze polskiego renesansu nie została podjęta próba promocji kobiet intelektualnie i erotycznie niezależnych ani stworzenia dyskursu, w którym wykształceni mężczyźni, często - tak jak Górnicki - na najlepszych włoskich uniwersytetach, musieliby się zmierzyć z emancypującą się kobiecością i innością seksualną.

Co prawda, literatura staropolska wykształciła kilka odmian erotyku, jednakże ujawniające się w nich relacje płciowe nie zostały do tej pory poddane głębszej, genderowej analizie ${ }^{22}$. Nie mogłaby ona pominać pytania o pozycje męskiego podmiotu w tego rodzaju tekstach i sposoby kształtowania się w nich męskich tożsamości. W epoce wojen religijnych (rzeź hugenotów w roku 1572 była ich preludium) męską duchowość bardzo często wyrażano za pomocą topiki militarnej. Zresztą

Zob. H. Dziechcińska, Kobieta $w$ życiu i literaturze XVI $i$ XVII wieku. Warszawa 2001, tu rozdz. 4: Kobieta w „Dworzaninie”: Baldassare”a Castiglione, Luisa Milana, Łukasza Górnickiego.

21 Zob. M. Wojtkow ska-Maksymik, „Gentiluomo cortigiano” $i$ „dworzanin polski”. Dyskusja o doskonałości człowieka $w$ „Il Libro del Cortigiano” Baldassarra Castiglionego $i w$ „Dworzaninie polskim" Łukasza Górnickiego. Warszawa 2007, s. 274. 
motywy batalistyczne - jak pisze Andrzej Borowski - pojawiały się również (to bardzo znamienne) w sarmackiej liryce erotycznej ${ }^{23}$.

Filozofia nowożytna w Europie Zachodniej ostatecznie doprowadziła, zdaniem Connell, do upowszechnienia się męskości utożsamionej z rozumem, działaniem racjonalnym i etyką obowiązku. Kartezjusz oraz Kant przeciwstawiali rozum uczuciom i pożądaniu. Co więcej, rozum miał za zadanie w obu tych koncepcjach filozoficznych stać na straży uczuć i pożądania. Na tym założeniu opierała się racjonalistyczna etyka ${ }^{24}$. Znalazło to swoje odzwierciedlenie w binarnym, wprzęgniętym $\mathrm{w}$ mechanizm fallogocentryzmu postrzeganiu relacji płciowych, a także w stereotypowym rozróżnieniu między męską racjonalnością, z której uczyniono cywilizacyjną i antropologiczną normę, a kobiecą uczuciowością, w najlepszym razie poddawana społecznemu nadzorowi.

Dominujący w kulturze staropolskiej model męskości sarmackiej ewoluował, jak się wydaje, w innym kierunku. Cechowało go nastawienie raczej antykartezjańskie, co należy rozumieć jako przewagę emocjonalności nad racjonalnością, ale też jako bardziej bezpośredni, niezdystansowany, nieuprzedmiotowiony stosunek do rzeczywistości. W stereotypowym obrazie Sarmaty (pytanie - na ile rzeczywistym?) rubaszny charakter dopełniały cielesna ekstensywność, ksenofobiczne uprzedzenia i bigoteryjna religijność. Mężczyzna sarmacki doświadczał wolności nie w klaustrofobicznej przestrzeni biblioteki czy sali wykładowej, lecz na otwartej przestrzeni pola bitewnego. Nie identyfikował się z wartościami intelektualnymi, tylko z ziemiańskimi i militarnymi. Przy czym idea wojennego męstwa, szczególnie pod wpływem potrydenckiej ideologii jezuickiej, została wpisana w sakralizujący kontekst etyki i historiozofii chrześcijańskiej.

\section{Historia męskości a epoka kolonializmu}

Podbój Nowego Świata przez najsilniejsze politycznie i ekonomicznie państwa europejskie był prezentowany w wykładni ideologicznej jako cywilizacyjna misja polegająca na niesieniu ludom pogańskim i barbarzyńskim chrześcijańskiej wiary oraz światła rozumu. „Misjonarzami”, zauważa Connell, w pierwszej kolejności okazali się wyselekcjonowani mężczyźni tworzący specyficzne grupy homospołeczne - żeglarze i żołnierze. Idea podboju, nie tylko w odniesieniu do geograficznych terytoriów, stanęła zatem w centrum męskiego etosu, sprzężonego ściśle z europejskim imperializmem. Epoka kolonializmu sprawiła, że męską obsesją stał się, oprócz idei podboju, również imperatyw kontroli - czy to nad terytoriami i ich granicami, czy to nad kobietami, czy też nad własną tożsamością.

Rzeczpospolita Obojga Narodów nie posiadała zamorskich kolonii, niemniej jednak polskim królom, magnaterii czy szlachcie nie były przecież obce aspiracje imperialne. Ekspansja lądowa, szczególnie po unii lubelskiej w 1569 roku, doprowadziła do opanowania obszernych terytoriów na wschodzie i południu, obejmu-

A. B or ow ski, Kobieta. Hasło w: Stownik sarmatyzmu: idee, pojęcia, symbole. Red. ... Kraków 2001, s. 83.

24 Zob. V. J. Seidle r, Rediscovering Masculinity. Reason, Language and Sexuality. London 1989, tu rozdz. 2: Reason. 
jących ziemie Litwinów, Białorusinów i Ukraińców. Historycy oraz literaturoznawcy z coraz większą dobitnością podkreślają, że polska obecność na Ukrainie miała de facto charakter kolonialny, co przez długi czas było przesłaniane przez mit jagielloński, a jeszcze bardziej przez sentymentalno-nostalgiczny, szczególnie w okresie zaborów i potem w Dwudziestoleciu międzywojennym, mit Kresów ${ }^{25}$. Wyłania się zatem pytanie o to, na ile bliska była polskiej szlachcie sama idea podboju terytorialnego i kulturowego, jak mocno została ona osadzona w ideologii sarmatyzmu i do jakiego stopnia pojawia się w literaturze staropolskiej?

Niewątpliwie bardzo istotnym komponentem ideologii sarmackiej stał się, uzasadniony zresztą rzeczywistymi zagrożeniami zewnętrznymi, imperatyw obrony i kontroli granic, który hasłem „antemurale christianitatis” wpisywał się w koncepcję religijno-cywilizacyjnej „misji”26. Wojny prowadzone w Polsce XVII wieku z wrogami obcymi religijnie i wyznaniowo - z prawosławną Rosją i Kozaczyzną, z islamską Turcja, z protestancką Szwecja - stwarzały zagrożenie nie tylko dla integralności terytorialnej państwa, ale również dla tożsamości etnicznej, religijnej, kulturowej. Czy także dla męskości sarmackiej? Czy imperatyw obrony i kontroli granic, sprzeczny z przekonaniami o wybujałym szlacheckim indywidualizmie, o przywiązaniu do „złotej wolności”, o rubasznym temperamencie i anarchistycznym warcholstwie, odnosił się do limitowania i cenzurowania męskiej tożsamości? Historycy epoki staropolskiej podkreślali, że w charakterystykach wrogów zewnętrznych pojawiały się często ksenofobiczne heterostereotypy płciowe i seksualne ${ }^{27}$.

Zagadnienie męskości sarmackiej i ewentualnie różnych jej odmian wiąże się zatem $\mathrm{z}$ pytaniem o to, która $\mathrm{z}$ postaw - ekspansywna czy defensywna, w niej/nich dominowała. Polska szlachta, przy całym swoim zróżnicowaniu, tworzyła ideologicznie dość silnie zintegrowaną homospołeczną męską wspólnotę, skonsolidowaną etnogenetycznym mitem, apoteozą sarmackiego wojownika stojącego na straży granic chrześcijańskiego świata, ideą stanowego braterstwa, mobilizacją wobec zewnętrznych wrogów i swoistą na tle europejskim kultura. Warto postawić pytanie - na ile ta stanowa i męsko-męska zwartość, zapewniająca przywileje polityczne i społeczne, dokonywała się poprzez ekskluzję wszelkiej inności: klasowej, etnicznej, religijnej, płciowej, seksualnej? Czy nie prowadziła nieuchronnie do postaw ksenofobicznych?

Zob. przełomowe prace francuskiego historyka D. B e a u v o i s: Mit „kresów wschodnich”, czylijak mu położyć kres. W zb.: Polskie mity polityczne XIX i XX wieku. Red. W. W r z e s iń s ki. Wrocław 1994; Trójkąt ukraiński. Szlachta, carat i lud na Wołyniu, Podolu i Kijowszczyźnie 1793-1914. Przeł. K. Rutkow ski. Lublin 2005. Ważnym głosem stała się również książka J. S owy Fantomowe ciało króla. Peryferyjne zmagania z nowoczesna forma (Kraków 2011).

J. Ni edź wi e dź, Antemurale. Hasło w: Stownik sarmatyzmu.

Zob. Z. K uc howi cz, Człowiek polskiego baroku. Łódź 1992, tu informacje w rozdz. 17: Czarny erotyzm. - J. Tazbir, Dewiacje obyczajowe. W: Studia nad kultura staropolska. Kraków 2001. Zwrócili na to uwagę także Nastulczyk i Oczko (op. cit., s. 224-226): „Homoseksualność była [...] nad wyraz często jednym ze znaków Innego zagrażającego homogeniczności sarmackiego świata: Turka, muzułmanina, Kozaka lub też plebejusza chcącego dostać się do szlacheckiego stanu”; „Skojarzenie homoseksualności ze Wschodem i "barbarzyństwem“ było niezwykle silne” (ibidem, s. 234). 


\section{Historia męskości a rozwój miast i kultury miejskiej}

Od końca średniowiecza największe miejskie ośrodki Europy Zachodniej zaczęły pełnić funkcję centrów gospodarki kapitalistycznej, przyczyniając się tym samym do przełomowych zmian społecznych i kulturowych. Życie codzienne stało się równocześnie bardziej anonimowe i ściślej regulowane, były to jednak warunki, które umożliwiały krzewienie się postaw indywidualizmu. W kulturze miejskiej i kapitalistycznej dokonała się, zdaniem Connell, instytucjonalizacja nowej formy męskości - odwołującej się już nie do rycerskiego etosu walki i honoru, tylko do mieszczańskiego etosu pracy. Ponadto procesy urbanizacyjne pociagały za soba przemiany obyczajowe: zaczęły się ujawniać subkultury seksualne.

Wielkie miasta w epoce wczesnonowoczesnej nie odgrywały zbyt doniosłej roli w polskiej kulturze. Ich rozwój dokonywał się z dużym opóźnieniem w porównaniu z Europą Zachodnią i przy niechętnym nastawieniu ziemiańsko-chłopskiego społeczeństwa. Zablokowanie przez szlachtę wpływu mieszczan na życie polityczne, na co zwrócił ostatnio uwagę Jan Sowa, okazało się „brakiem”, który spowodował, że Polska już od XV wieku zaczęła się rozwijać pod względem ekonomicznym i społecznym odmiennie niż Europa Zachodnia ${ }^{28}$.

Nasuwa się zatem pytanie, jak ten trwający do drugiej połowy XIX wieku, a może jeszcze dłużej, niedorozwój kultury mieszczańskiej w Polsce wpłyną na ewolucję relacji płciowych. Wydaje się, że jest tu coś na rzeczy. W Europie Zachodniej rozpoczął się przybierający na dynamice proces dyferencjacji społecznej. Zmiany obyczajowe dokonywały się szybciej i radykalniej w mieście niż na wsi. W społecznościach miejskich kobiety zapewniały sobie większy udział w zarządzaniu wspólnym majątkiem ${ }^{29}$, znajdowały bardziej sprzyjające warunki do stowarzyszania się i tym samym inicjowania ruchów emancypacyjnych. W Polsce te procesy na długi czas zostały odroczone. Trwał w najlepsze tradycyjny, patriarchalny układ relacji płciowych. Rachitycznością stanu mieszczańskiego można też tłumaczyć nikłą obecność osób homoseksualnych w publicznym i symbolicznym wymiarze kultury staropolskiej ${ }^{30}$.

W historii męskości w Polsce, przynajmniej do 1863 roku, najistotniejsze okazało się to, że nie nastąpił moment konfrontacji $z$ wyzwaniami kapitalizmu i kultury miejskiej. To oznaczało - przyjmując oczywiście pewne uproszczenie - że mężczyźni nie mieli możliwości tworzenia swojej tożsamościowej identyfikacji wokół mieszczańskiego etosu pracy i przedsiębiorczości. Nie tylko cywilizacyjne zacofanie, ale także późniejsza sytuacja zniewolenia w okresie zaborów wymusiły trwanie przy tradycyjnym, rycerskim i sarmackim etosie walki z zewnętrznymi wrogami.

Ten polityczny, ekonomiczny i społeczny niedorozwój znalazł swój wyraz w li-

S ow a, op. cit., s. 114-126.

Zob. ibidem, s. 564.

Badacze zajmujący się homoseksualnością staropolską, N a s t u lc zy k i O c z k o (op. cit., s. 57), stwierdzają: „W Rzeczypospolitej, kraju małych miast, zniewolonych i przypisanych do ziemi chłopów, wąłłego mieszczaństwa i opartego na tradycji rodzinnej rzemiosła i handlu, najwyraźniej nie wykształciły się [...] warunki sprzyjające powstaniu wielkomiejskich społeczności osób homoseksualnych, z jednej strony bardziej wyemancypowanych, z drugiej zaś, ze względu na swoją liczebność, narażonych tym samym na bycie zauważonymi, a co za tym idzie, na prześladowania i procesy”. 
teraturze - „Miasto aż do XIX w. zajmowało podrzędną pozycję w hierarchii polskich tematów literackich" ${ }^{31}$. Nie znaczy to jednak, że w epoce renesansu i wczesnego baroku nie istniała w Polsce „literatura mieszczańska” (cudzysłów wskazuje wszakże na pewną umowność tego terminu); miała ona nawet swoją dość wyraźną reprezentację $^{32}$. Ze stanu mieszczańskiego wywodziło się przynajmniej kilku cenionych twórców. W paru dziełach przewijają się opisy urody miast i sceny z życia mieszczan $^{33}$. Niektórzy autorzy dostrzegali cywilizacyjna, ekonomiczną przede wszystkim, przewage ośrodków miejskich nad szlacheckimi folwarkami. Sowa pisał:

Podstawowy zarzut, jaki można sformułować przeciwko modelowi folwarczno-pańszczyźnianemu, to jego zły, a nawet fatalny strukturalny wpływ na trajektorię rozwoju polskiego społeczeństwa, polityki, kultury i gospodarki ${ }^{34}$.

Kapitalizm wyzwolił mobilność na rynku pracy, naruszył feudalne struktury społeczne, zaktywizował ekonomicznie, ale też intelektualnie jednostki, stworzył nowy typ kultury.

Problem polegał na tym, że nie wykształciła się żadna afirmatywna ideologia mieszczańska, która swoim oddziaływaniem byłaby w stanie doprowadzić do istotnych zmian politycznych i społecznych, a równocześnie stanowiłaby przynajmniej alternatywę dla ziemiańsko-militarystycznej ideologii sarmackiej. Jedyny znaczący wyjątek, potwierdzający regułę, to Walenty Roździeński, autor pochodzacy z wielopokoleniowej rodziny hutników, który w poemacie Officina ferraria, abo Huta i warstat z kuźniami szlachetnego dzieła żelaznego (1612), szczególnie w jego końcowej części, zatytułowanej Własny konterfekt, abo Wyobrażenie żywota kuźniczego, zamieścił pochwałę ciężkiej, choć również przynoszącej satysfakcję pracy hutnika, wyraźnie zaznaczając swoją zawodową, stanową, mentalnościową i w jakimś sensie moralną odmienność. Przyjmując perspektywę badań maskulinistycznych, można by dowodzić, że $z$ tekstu Roździeńskiego wyłania się fantazmat męskiego ciała, które zostało zahartowane i okaleczone (w opozycji do poranionego ciała żołnierza) przez kuźnicza pracę, czy też na poziomie bardziej symbolicznym - przeszło alchemiczną próbę ognia.

\section{Historia męskości a wojny dynastyczne i domowe w Europie}

Europa w XVI i XVII wieku stała się arena okrutnych wojen religijnych, które w stuleciach XVII i XVIII przekształciły się w wojny dynastyczne, powodując - jak pisze złośliwie Connell - przemieszczenie się kilku królów i biskupów. Był to jednak okres ważny w historii europejskich męskości. Konflikty zbrojne, przyczyniając się

S. To ma s zew ski, Miasto. Hasło w: Stownik literatury polskiej XIX wieku. Red. J. B a chó rz, A. Kowalczy k owa. Wyd. 2. Wrocław 1994, s. 543.

Zob. S. Grzeszczuk, Literatura mieszczańska. Hasło w: Stownik literatury staropolskiej. Red. T. Michałowska. Wyd. 2, popr. i uzup. Wrocław 1998.

Zob. Cz. Hern a s, Barok. Wyd. 7. Warszawa 1999, s. 319-330. Z prac wydanych ostatnio zob. W. W oj t o w i c z, Między literatura a kultura. Studia o „literaturze mieszczańskiej” przełomu XVI i XVII wieku. Szczecin 2010.

S ow a, op. cit., s. 174. 
do powstania silnych, scentralizowanych państw, skonsolidowały patriarchalny porządek społeczny. Monarchie absolutne wzmacniały i instytucjonalizowały męską władzę. Nowoczesne państwa, kierując się ideą imperialnego podboju, swój sposób funkcjonowania oparły na zawodowej armii. Dorzućmy do tego uwagę oczywista - wojny jako wydarzenie historyczne, ale też jako doświadczenie egzystencjalne, od zawsze odgrywały kluczową rolę w ustanawianiu męskich tożsamości, opierających się na etosie walki i honoru ${ }^{35}$.

W wieku XVIII - jak pisze Connell - w Europie i Ameryce Północnej ukonstytuował się porządek płci, w którym męskość, w znaczeniu już nowoczesnym, traktowano jako upłciowiony indywidualny charakter, definiowany w opozycji do kobiecości oraz zinstytucjonalizowany przez ekonomię i państwo.

Historia Polski w wieku XVII i XVIII to przede wszystkim epoka wojen z religijnie i kulturowo odmiennymi sąsiadami, a równocześnie epoka rokoszy wszczynanych przez zbuntowanych przedstawicieli stanu szlacheckiego, korzystających z przywileju „Złotej wolności”. Nie doprowadziły one, tak jak w Europie Zachodniej, do wzmocnienia i centralizacji państwa, lecz przeciwnie - do politycznego, ekonomicznego i militarnego rozkładu Rzeczypospolitej. Szlachcic nie tylko gospodarował na folwarku (czerpiąc korzyści z niewolniczej pracy pańszczyźnianej), ale też musiał uczestniczyć w działaniach militarnych - taki ideał parenetyczny propagował chociażby Rej w Żywocie człowieka poczciwego. Ideologia sarmacka opierała się zatem na dwóch podstawowych ideach definiujących męskie role społeczne: ziemiańskiej i rycerskiej, dopełniających się w figurze Cyncynata ${ }^{36}$. „Nie mógł się zwać szlachcicem, nie bywszy żołnierzem" - pisał o reprezentantach swojego stanu Wacław Potocki ${ }^{37}$. Pasek ukazywał się podobnie: jako utraque civis, dwojaki obywatel - „bom i szlachcic, bom i żołnierz" 38 . Istotne w tych zestawieniach wydaje się, że pokojowy ideał ziemiański nie miał wartości sam w sobie, jego nieodzownym i komplementarnym dopełnieniem musiał być ideał wojowniczości żołnierskiej. Jak pisała o tym Alina Nowicka-Jeżowa:

Łącząc w sobie tak różnorodne i nośne elementy, barokowa idea wojny zawładnęła społeczeństwem szlacheckim, kształtowała system wartości oraz poczucie tożsamości stanowej i narodowej, a służąca jej literatura stała się wyrazem najżywszych emocji indywidualnych i społecznych ${ }^{39}$.

Perspektywa badań maskulinistycznych pokazuje, że barokowa idea wojny kształtowała przede wszystkim męski system wartości, poczucie męskiej tożsamo-

Zob. J. Nagel, War. Hasło w: International Encyclopedia of Men and Masculinities. Ed. M. Fl o o d, J. K. Gardiner, B. Pease, K. Pringle. London-New York 2007. Szerzej pisałem o tym w swojej książce Wojna - męskość - literatura (Słupsk 2013).

36 Zob. A. Nowi cka-J éżow a, Barok polski między Europa i Sarmacja. Cz. 1: Profile i zarysy catości. Warszawa 2009-2011, s. 237. Oprócz tych dwóch idei: ziemiańskiej i rycerskiej, autorka wyodrębnia jeszcze trzecią - obywatelską. Idealny szlachcic miał być zatem mówca, rolnikiem i żołnierzem.

37 Poeci polskiego baroku. T. 2. Oprac. J. S okołows ka, K. Żu kowska. Warszawa 1965, s. 95.

38 J. Ch. Pa s e k, Pamiętniki. Wstęp, objaśnienia W. C za pli ń s ki. Wyd. 4, zmien. i uzup. Wrocław 1968, s. 205-206. BN I 62.

39 Nowicka-Jeżowa, op. cit., s. 262. 
ści, tworzyła męsko-męskie więzi homospołeczne, a związana $z$ nią literatura odzwierciedlała męskie emocje indywidualne i zbiorowe.

W drugiej połowie XVII wieku - zauważa Janusz Pelc - wzorzec homo militans zdobył przewagę nad wzorcem homo ludens, łaczącym się z ideałem ziemiańskim i urokami życia na wsi ${ }^{40}$. Średniowieczne tradycje rycerskie, na równi $z$ etnogenetycznym mitem sarmackim, stały się dla polskiej szlachty bardzo istotnym odniesieniem kształtującym stanową tożsamość i poczucie wojennego, męskiego braterstwa. Ideologia szlachecka, nawiązująca do idei antycznej virtus oraz etosu rycerskiego, wykorzystując propagandową funkcję literatury, opierała się na kulcie męstwa utożsamianego $\mathrm{z}$ męskością wojowniczą. Konflikty zbrojne $\mathrm{z}$ innowiercami dość łatwo dawały się przetransponować w literaturze baroku na ideę „wojny pobożnej”. Sakralizacji została poddana także militarystyczna męskość sarmacka, szlachecki żołnierz awansował bowiem do rangi rycerza chrześcijańskiego, stojącego na straży prawdziwej wiary ${ }^{41}$.

Męskość sarmacka, która w wiekach XVII i XVIII osiągnęła w Polsce status hegemoniczny, na tle ówczesnej Europy stanowiła socjokulturowy ewenement. Nie kształtowały jej racjonalizm, mieszczański kapitalizm ani protestancki duch przedsiębiorczości, lecz odwołujący się do tradycji rycerskich etos walki ściśle powiązany z ideologia potrydenckiego katolicyzmu. Sarmacki męski habitus, chociaż nie odżegnywał się od ideałów ziemiańskich, to jednak formował się przede wszystkim pod wpływem wzorców żołnierskich. Pasek tym spośród przedstawicieli szlachty, którzy zbyt długo i wygodnie żyli w pokoju, zarzucał zniewieściałośćc ${ }^{42}$. Identyfikacja $z$ wartościami militarystycznymi pociagała za sobą konsekwencje dotyczace relacji płciowych. Wstępne rozpoznania badawcze dowodzą, że wzorzec męskości sarmackiej wymusił pojawienie się wizerunku kobiety „umężczyźnionej”, rycerskiej i pobożnej, nie stroniącej od obyczajowej rubaszności ${ }^{43}$. Kultura staropolska utrwaliła jednak patriarchalny porządek płci $^{44}$, „niewzruszenie panowała patria potestas, czyli absolutna władza ojcowska” ${ }^{45}$. Kobiety, przypisane do ról macierzyńskich i gospodarskich, nie uczestniczyły, tak jak coraz częściej działo się na zachodzie Europy, w życiu intelektualnym i literackim ${ }^{46}$. Wizerunki kobiet kreślone przez męskich autorów świadczyły nierzadko o mizoginizmie ${ }^{47}$.

Hegemonia męskości sarmackiej, opartej na ideałach żołnierskich i ziemiańskich, oznaczała marginalizację w kulturze staropolskiej innych wzorów męskich zachowań, jak chociażby tożsamościową identyfikację $z$ mieszczańskim etosem pracy czy też z zapożyczonym $\mathrm{z}$ Francji stylem préciosité (w pewnej mierze próbował

J. Pelc, Sarmatyzm a barok. W zb.: Problemy literatury staropolskiej. Red. ... Seria 1. Wrocław 1972, s. 43.

Zob. M. Lenart, Miles pius et iustus. Żołnierz chrześcijańskiej katolickiej wiary $w$ kulturze i piśmiennictwie dawnej Rzeczypospolitej (XVI-XVIII w.). Warszawa 2009.

Pa s e k, op. cit., s. 544.

Zob. E. Kraskowska, K. Filipowicz-Tokarska, Sarmatyzm, pteć, feminizm. W zb.: Nowoczesność i sarmatyzm. Red. P. Czapliński. Poznań 2011.

Zob. B or ow ski, op. cit., s. 81.

G. U rb a n, Rodzina. Hasło w: Stownik sarmatyzmu, s. 166.

Zob. Dziechcińska, op. cit., s. 92-103.

Zob. Urban, op. cit., s. 167. 
tego np. Jan Andrzej Morsztyn). W epoce zaborów, kolejnych insurekcji, powstań, konspiracji, represji męskość w Polsce została ściśle powiązana $\mathrm{z}$ etosem żołnierskości, bohaterstwa, ofiarności i martyrologii. Zdaniem Marii Janion, ten wzór przetrwał aż do czasów nam współczesnych: „Polska kultura narodowa jest kulturą wybitnie męską. W jej obrazie na plan pierwszy wysuwają się związki homospołeczne, więzi męskiego braterstwa i przyjaźni”"48. Historyczne trajektorie męskości w Polsce sięgają czasów bardzo odległych. Zagłębienie się w tę przeszłość umożliwia etiologiczną diagnozę kondycji współczesnych polskich mężczyzn.

\title{
Ostatnia uwaga
}

Pisanie historii męskości jest w istocie „przepisywaniem” historii kultury, w takim znaczeniu, jakie temu pojęciu nadał Jean-François Lyotard ${ }^{49}$. W tym przedsięwzięciu badawczym chodzi o ujawnienie tego, co zawsze istniało w przeszłości, ale było ukryte albo nazbyt przeźroczyste i bezrefleksyjnie traktowane jako normatywne. Nauki społeczne i humanistyczne, pod wpływem impulsu wysłanego przez ruch feministyczny, doprowadziły do tego, że kategorie takie, jak płeć, kobiecość, męskość, seksualność stały się widzialne. Koncepcji réécriture towarzyszy również cel emancypacyjny, który Lyotard wiąże z tym, co Freud nazwał „prze-pracowywaniem [Durcharbeitung]" ${ }^{0}$. Łacińska emancipatio znaczyła pierwotnie uwolnienie się syna spod zależności od autorytarnej władzy ojca, wyrwanie się z objęć krępującego swobodę paternalizmu. Projekt przepisywania historii w taki sposób, aby odsłonić w niej odyseję męskości, jest zapewne zajęciem nie tylko badawczym, ale także terapeutycznym.

\author{
Abstract \\ TOMASZ TOMASIK Pomeranian University, Słupsk
}

REMARKS ON STILL UNWRITTEN HISTORY OF MASCULINITY IN POLAND

The article presents the fundamental methodological assumptions which, according to the author, should be considered in a project of writing a history of masculinity in Poland. It follows that it: 1) is a socio-cultural construct, 2) shows many variants, 3) is definable also in relations to women, 4) sets a matrix of normativeness in culture, 5) is viewed in various cultures as a task, 6) when reconstructed on the basis of literary works, history of males is a narration which arranges the textual representations of masculinity. The second part of the paper indicates most crucial processes and situations decisive about early modern history of masculinity in Europe and in Poland, namely 1) a crisis of cultural formation of Christianity, 2) colonial expansion, 3) development of cities and urban culture, 4) civil and dynastic wars.

M. J a n i o n, Niesamowita Słowiańszczyzna. Fantazmaty literatury. Kraków 2007, s. 267.

J.-F. Ly otard, Przepisać nowożytność. W zb.: Postmodernizm a filozofia. Wybór tekstów. Red. S. Czerniak, A. Szahaj. Warszawa 1996 (przeł. W. Szydłowska, przejrzał S. Czerniak). Ibidem, s. 48. 